\title{
Inhibition of all-TRANS-retinoic acid metabolism by RI 16010 induces antitumour activity
}

J Van heusden ',5, R Van Ginckel', H Bruwiere', P Moelans', B Janssen', W Floren', BJ van der Leede',
J van Dun', G Sanz, M Menet ${ }^{3}$, L Dillen', C Van Hove', G Willemsens', M Janicot*, and W Wouters

'Department of Oncology Discovery Research, Johnson \& Johnson Pharmaceutical Research \& Development, Turnhoutseweg 30, B-2340 Beerse, Belgium;

${ }^{2}$ Department of Metabolic Disorders, Johnson \& Johnson Pharmaceutical Research \& Development, Turnhoutseweg 30, B-2340 Beerse, Belgium:

${ }^{3}$ Department of Medicinal Chemistry, Johnson \& Johnson Pharmaceutical Research \& Development, Val-de-Reuil, France; ${ }^{4}$ Drug Evaluation, Johnson \&

Johnson Pharmaceutical Research \& Development, Turnhoutseweg 30, B-2340 Beerse, Belgium

\begin{abstract}
All-trans-retinoic acid is a potent inhibitor of cell proliferation and inducer of differentiation. However, the clinical use of all-transretinoic acid in the treatment of cancer is significantly hampered by its toxicity and the prompt emergence of resistance, believed to be caused by increased all-trans-retinoic acid metabolism. Inhibitors of all-trans-retinoic acid metabolism may therefore prove valuable in the treatment of cancer. In this study, we characterize RII6010 as a new anticancer drug that is a potent inhibitor of all-trans-retinoic acid metabolism. In vitro, RI I 6010 potently inhibits all-trans-retinoic acid metabolism in intact T47D cells with an $\mathrm{IC}_{50}$-value of $8.7 \mathrm{nM}$. In addition, RI I 6010 is a selective inhibitor as indicated by its inhibition profile for several other cytochrome P450-mediated reactions. In T47D cell proliferation assays, RII60I0 by itself has no effect on cell proliferation. However, in combination with all-trans-retinoic acid, RII6010 enhances the all-trans-retinoic acid-mediated antiproliferative activity in a concentration-dependent manner. In vivo, the growth of murine oestrogen-independent TA3-Ha mammary tumours is significantly inhibited by RII6010 at doses as low as $0.16 \mathrm{mg} \mathrm{kg}^{-1}$. In conclusion, RI I60I0 is a highly potent and selective inhibitor of all-trans-retinoic acid metabolism, which is able to enhance the biological activity of all-trans-retinoic acid, thereby exhibiting antitumour activity. RII6010 represents a novel and promising anticancer drug with an unique mechanism of action. British Journal of Cancer (2002) 86, 605-6I I. DOI: 10.1038/sj/bjc/6600056 www.bjcancer.com
\end{abstract}

(C) 2002 Cancer Research UK

Keywords: RA; metabolism; inhibitor; CYP26AI; RII60I0

All-trans-retinoic acid (RA) is a naturally occurring retinoid that is well-known to inhibit cell proliferation and to induce differentiation (Hong and Itri, 1994; Moon et al, 1994). However, the clinical use of RA in the treatment of cancer is significantly hampered by the prompt emergence of resistance, which is believed to be caused by increased RA metabolism (Muindi et al, 1992, 1994; Lee et al, 1993; Miller, 1998). RA is metabolized by CYP26A1, an inducible cytochrome P450-dependent enzyme, that inactivates RA by 4 -hydroxylation of the $\beta$-ionone ring (White et $a l$, 1997). This tightly-controlled negative feedback mechanism limits the availability of RA and thereby also its biological activity. Therefore, increasing levels of RA by inhibition of its metabolism might prove an innovative approach to cancer treatment.

Previously, we have identified liarozole-fumarate as an inhibitor of RA metabolism (Wouters et al, 1992). In vitro, liarozole-fumarate has been shown to enhance both the antiproliferative and differentiation-inducing activity of RA (Wouters et al, 1992; Van heusden et al, 1996, 1998). In vivo, liarozole-fumarate increases endogenous RA levels both in plasma and tissues (Smets et al, 1995). In several preclinical tumour models, liarozole-fumarate

\footnotetext{
*Correspondence: Dr M Janicot; E-mail: mjanicot@janbe.jnj.com ${ }^{5}$ Current address: GIMV - Venture Capital, Life Sciences \& Biotechnology, Karel Oomsstraat 37, B-2018 Antwerp, Belgium; E-mail: jimvh@gimv.be Received II January 200 I; revised II October 200 I; accepted 6 November 2001
}

has been shown to exhibit antitumour activity (Van Ginckel et al, 1990; Dijkman et al, 1994; Smets et al, 1995), linked to increased levels of RA within the tumour (Smets et al, 1995). In cancer patients, liarozole-fumarate has been shown to increase the half-life of orally administered RA and 13-cis-retinoic acid (Westarp et al, 1993; Achkar et al, 1994; Miller et al, 1994). However, one of the limitations to the use of liarozole-fumarate was its lack of specificity. It was shown to inhibit also other cytochrome P450-mediated reactions (Vanden Bossche, 1992) and affect plasma hormone levels in volunteers (Bruynseels et al, 1990).

This lack of specificity might partly explain the limited risk benefit ratio observed in cancer patients. A more potent and selective inhibitor is therefore required to improve the clinical efficacy of inhibitors of RA metabolism. In the present study, we identify R116010 (Figure 1) as a highly potent and selective second-generation inhibitor of RA metabolism that induces antitumour activity.

\section{MATERIALS AND METHODS}

\section{Drug and chemicals}

R116010, [S- $\left.\left(\mathrm{R}^{\star}, \mathrm{R}^{\star}\right)\right]-\mathrm{N}$-[4-[2-(dimethylamino)-1-(1H-imidazole1-yl)propyl]-phenyl]-2-benzothiazolamine, and liarozole-fumarate, \pm -5-[(3-chlorophenyl)( $1 H$-imidazole-1-yl)methyl]-1H-benzimidazole (E)-2-butenedioate (2:3) were synthesized at the Department of Medicinal Chemistry (Johnson \& Johnson Pharmaceutical Research \& Development, Val-de-Reuil, France). Compounds were 
<smiles>CC(C(c1ccc(Nc2nc3ccccc3s2)cc1)n1ccnc1)N(C)C</smiles>

R116010

Figure I Chemical structure of RII60 I0, [S-(R*, R*)]-N-[4-[2-(dimethylamino)-I-(I H-imidazole- |-y|)propyl]-phenyl]-2-benzothiazolamine.

dissolved to an initial concentration of $10 \mathrm{mM}$ in DMSO. Further dilutions were made in culture medium. $\left[11,12-{ }^{3} \mathrm{H}(\mathrm{N})\right] \mathrm{RA}$ $\left(30 \mathrm{Ci} \mathrm{mmol}^{-1}\right)$ was obtained from NEN Life Science Products (Boston, MA, USA). Unlabelled RA was purchased from Serva (Heidelberg, Germany) and dissolved to an initial concentration of $4 \mathrm{mM}$ in ethanol. Further dilutions were made in culture medium. All-trans-retinoic acid was used in a dark-room with yellow illumination. Final solvent concentrations in the in vitro assays were always less than $0.5 \%(\mathrm{v} / \mathrm{v})$. This solvent concentration had no effect in the respective assays.

\section{Cell culture}

Human T47D breast cancer cells - purchased from the American Type Culture Collection (Rockville, MD, USA) - were cultured in RPMI 1640 medium supplemented with $10 \%$ (v/v) FBS, $2 \mathrm{mM} \mathrm{L-}$ glutamine, $50 \mu \mathrm{g} \mathrm{ml}^{-1}$ gentamicin, and $10 \mu \mathrm{g} \mathrm{ml}^{-1}$ insulin (all reagents from Life Technologies, Gent, Belgium). Cells were grown in a humidified incubator $\left(5 \% \mathrm{CO}_{2}, 95 \%\right.$ air $)$ at $37^{\circ} \mathrm{C}$ and were Mycoplasma-free as tested by the Mycoplasma T.C. kit (Gen-Probe Incorporated, CA, USA).

\section{Microcolumn assay for RA metabolism}

RA metabolism was quantitatively determined using the microcolumn assay as described previously (Krekels et al, 1997). Briefly, T47D cells were pretreated for $16 \mathrm{~h}$ with $1 \mu \mathrm{M}$ RA to induce RA metabolism. Cells were then washed twice with culture medium,

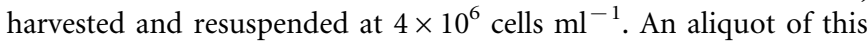
cell suspension $(450 \mu \mathrm{l})$ was incubated for $90 \mathrm{~min}$ in the presence of $0.1 \mu \mathrm{M}\left[11,12-{ }^{3} \mathrm{H}(\mathrm{N})\right] \mathrm{RA}$, after which $2 \mathrm{ml}$ acetonitrile was added. After centrifugation for $10 \mathrm{~min}$ at $780 \mathrm{~g}$, the resulting deproteinized supernatant was acidified with $2.5 \mathrm{ml}$ of $40 \mathrm{~mm}$ acetic acid and applied to a $3 \mathrm{ml} \mathrm{C18}$ Bond Elut LRC column (Varian, Harbor City, CA, USA; pretreated with $4 \mathrm{ml}$ distilled water) under a vacuum of $127 \mathrm{mmHg}$ using VAC ELUT SPS-24 and the effluent was collected. The column was eluted with $1 \mathrm{ml} 40 \%$ acetonitrile and the effluent was collected in the same vial. Radioactivity in the collected effluent, containing the polar metabolites, was determined in a Packard Tricarb 4530 liquid scintillation analyzer. Optiphase 'Hi Safe II' (Wallac, Milton Keynes, UK) was used as a scintillator. Data are presented as mean \pm s.d. of three or four independent experiments. The $\mathrm{IC}_{50}$-values were calculated by non-linear regression analysis using SigmaPlot 4.01 software.

\section{HPLC analysis}

The T47D cell suspension was prepared as described above and $450 \mu \mathrm{l}$ was incubated with $0.1 \mu \mathrm{M}\left[11,12-{ }^{3} \mathrm{H}(\mathrm{N})\right] \mathrm{RA}$ for $90 \mathrm{~min}$. After centrifugation for $10 \mathrm{~min}$ at $780 \mathrm{~g}$, the supernatant was analyzed for the presence of RA metabolites. Reverse-phase HPLC analysis was carried out as described previously (Van heusden et al, 1998).

\section{In vitro cytochrome $\mathrm{P} 450$ isozyme specificity}

Metabolism of RA by CYP26A1 was measured in microsomes of T47D human breast cancer cells that were pretreated for $16 \mathrm{~h}$ with $1 \mu \mathrm{M}$ RA to induce RA metabolism. Microsomes were prepared exactly as described by Han and Choi (1996), and RA metabolism was measured as described by Van Wauwe et al (1994). The conversion of androstenedione to estrone by aromatase (CYP19) in human placental microsomes, the conversion of 17-hydroxy-20-dihydroprogesterone to testosterone by 17,20-lyase (CYP17) in rat testicular S10 fractions, and the $2 \alpha-, 7 \alpha-, 6 \beta$-, and $16 \beta$-hydroxylation of testosterone (CYP2C11, CYP2A1, CYP3A, CYP2B1/2) in rat liver microsomes were carried out as described (Vanden Bossche et al, 1990).

\section{Proliferation experiments (3-(4,5-dimethylthiazol-2-yl)- 2,5-diphenyl-2 $\mathrm{H}$-tetrazolium bromide assay)}

T47D cells were seeded in Falcon ${ }^{\circledR}$ 96-well cell culture plates (Life Technologies, Merelbeke, Belgium) at 2500 cells per well in a total volume of $150 \mu \mathrm{l}$. Cells were allowed to adhere to plastic for $24 \mathrm{~h}$. Drugs and/or medium were added to a final volume of $200 \mu \mathrm{l}$ (day 0 ). Cells were grown under these conditions for 7 days, with renewal of medium and drugs on days 2 and 5. On day 7, medium was renewed and $25 \mu \mathrm{l}$ MTT-solution was added, and cells were further incubated for $2 \mathrm{~h}$ in a cell incubator. The medium was aspirated and $25 \mu \mathrm{l}$ Sorensen glycine buffer $(0.1 \mathrm{M}$ glycine, $0.1 \mathrm{M}$ $\mathrm{NaCl} ; \mathrm{pH} 10.5)$ was added together with $100 \mu \mathrm{l}$ DMSO to solubilize the blue MTT-formazan product. After shaking for $10 \mathrm{~min}$ on a microplate shaker, the absorbance at $540 \mathrm{~nm}$ was determined using a $E_{\max }$ 96-well spectrophotometer (DPC, Grimbergen, Belgium). Data are presented as mean \pm s.d. of three or four independent experiments. Within an experiment, the result of each experimental condition is the mean of six replicate wells. The $\mathrm{IC}_{50}$-values were calculated by non-linear regression analysis using SigmaPlot 4.01 software.

\section{RT - PCR}

T47D cells were seeded in Nunc ${ }^{\mathrm{TM}} 6$-well plates at a concentration of $2 \times 10^{6}$ cells per well in $5 \mathrm{ml}$ medium. Cells were allowed to adhere to plastic for $24 \mathrm{~h}$. After indicated periods of time, total RNA was isolated using UltraSpec-II (Biotecx Laboratories, TX, USA) according to manufacturer's instructions. Three micrograms of total RNA was heated at $65^{\circ} \mathrm{C}$ for $5 \mathrm{~min}$ and rapidly cooled on ice. Then, 1500 ng oligo $\mathrm{d}(\mathrm{T})_{12-18}$ primer (Life Technologies, MD, USA) was added and CDNA was synthesized using $200 \mathrm{U}^{-1} \mathrm{l}^{-1} \mathrm{M}$ MLV RT (Life Technologies, MD, USA) in a RT reaction buffer (Life Technologies, MD, USA) supplemented with $20 \mathrm{U}^{-1}$ RNAsin (Life Technologies, MD, USA), and $500 \mu \mathrm{M}$ each dNTP (Perkin Elmer, CA, USA). The $60 \mu \mathrm{l}$ reaction mixture was incubated at $37^{\circ} \mathrm{C}$ for $1 \mathrm{~h}$, followed by a 4 min incubation at $90^{\circ} \mathrm{C}$ to inactivate the RT enzyme. Two microlitres of the RT reaction mix was used for the PCR reaction. Amplification was performed in a total volume of $50 \mu \mathrm{l}$ containing $2 \mu \mathrm{l} \mathrm{cDNA}, 5 \mu \mathrm{l} 10 \times \mathrm{PCR}$ reaction buffer (Boehringer Mannheim, Germany), $1 \mu \mathrm{l}$ sense primer $(20 \mu \mathrm{M}), 1 \mu \mathrm{l}$ antisense primer $(20 \mu \mathrm{M}), 4 \mu \mathrm{l}$ dNTPs (each at a concentration of $2.5 \mathrm{~mm}$; Perkin Elmer, CA, USA) and $0.25 \mu \mathrm{l}$ AmpliTaq Gold $\left(5 \mathrm{U}^{-1} \mathrm{l}^{-1}\right.$; Perkin Elmer, CA, USA). AmpliTaq Gold was activated by a $10 \mathrm{~min}$ incubation at $94^{\circ} \mathrm{C}$. The samples were then subjected to 30 or 24 cycles of amplification for CYP26A1 or $\beta_{2}$-microglobulin, respectively. Each cycle consisted of $1 \mathrm{~min}$ of denaturation at $92^{\circ} \mathrm{C}, 1 \mathrm{~min}$ of annealing at $55^{\circ} \mathrm{C}(\mathrm{CYP} 26 \mathrm{~A} 1)$ or $50^{\circ} \mathrm{C}\left(\beta_{2}\right.$-microglobulin), and $2 \mathrm{~min}$ of extension at $72^{\circ} \mathrm{C}$. At the end of the incubation an extra extension 
step was included $\left(10 \mathrm{~min}\right.$ at $\left.72^{\circ} \mathrm{C}\right)$. Ten microlitres of the PCR products were separated on a $1.3 \%(\mathrm{w} / \mathrm{v})$ agarose gel, and visualized by UV light illumination after ethidium bromide staining. Specific primers were obtained from Eurogentec (Seraing, Belgium). Their sequences were as follows: CYP26A1 sense primer

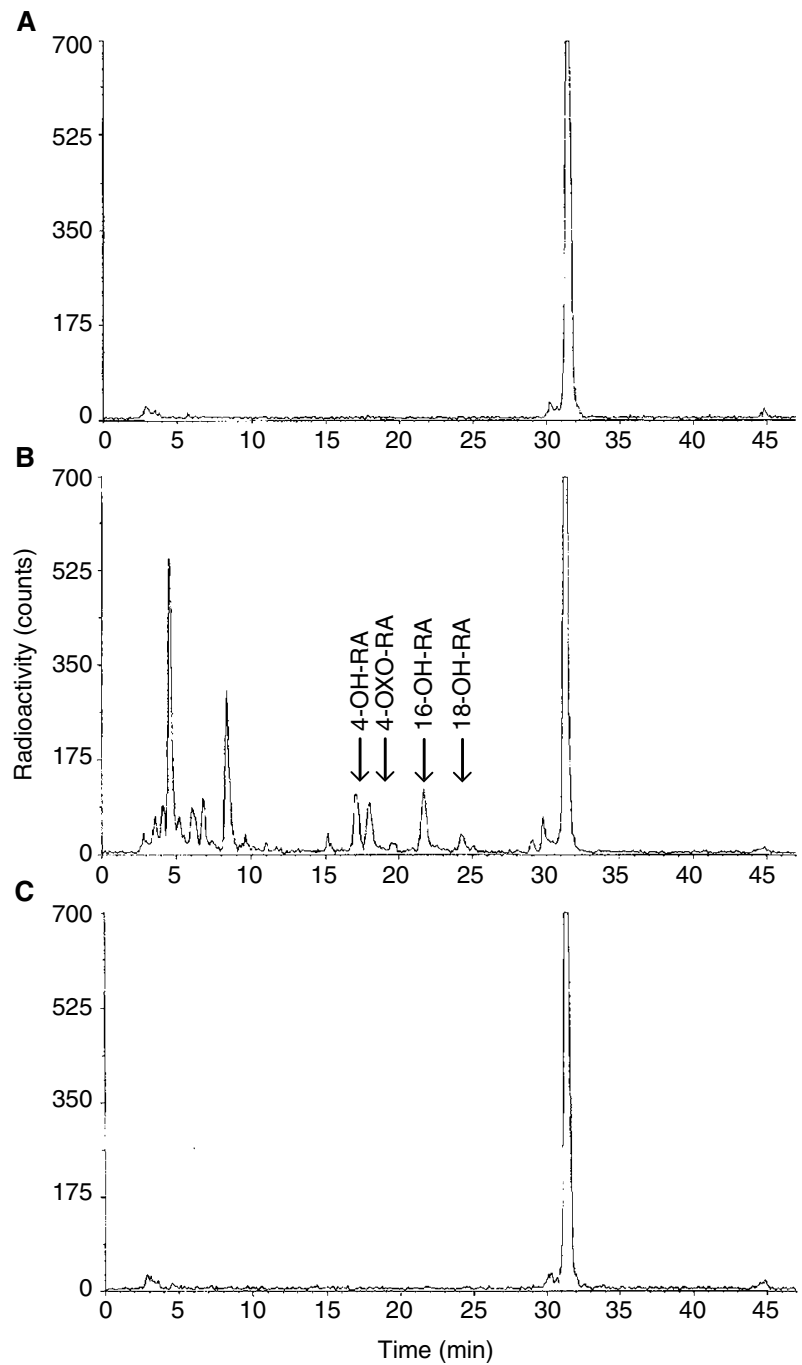

Figure 2 Reverse-phase HPLC analysis of radiolabelled RA metabolites formed in T47D human breast cancer cells. T47D human breast cancer cells were cultured under basal culture conditions $(\mathbf{A})$ or pretreated with I $\mu \mathrm{M}$ RA (B, C). Then, cells were collected and incubated with $0.1 \mu \mathrm{M}$ $\left[{ }^{3} \mathrm{H}\right] \mathrm{RA}$, either in the absence $(\mathbf{A}, \mathbf{B})$ or presence $(\mathbf{C})$ of I $\mu \mathrm{M} \mathrm{R} \mid \mathrm{I} 60 \mathrm{I0}$. Supernatants were analyzed by reverse-phase HPLC (I0).
5'-GCTGAAGAGTAAGGGTTTAC-3', and antisense primer 5'-CTTGGGAATCTGGTATCCAT- $3^{\prime}$ (yielding a PCR-product of $184 \mathrm{bp}) ; \beta_{2}$-microglobulin sense primer $5^{\prime}$-ACCCCCACTGAAAAAGATGA-3', and antisense primer 5'-ATCTTCAAACCTCCATGATG-3' (yielding a PCR product of $114 \mathrm{bp}$ ).

\section{TA3-Ha mammary carcinoma model}

Oestrogen-independent TA3-Ha murine mammary carcinoma cells were grown by weekly intraperitoneal passage in vivo. Cells $\left(1.5 \times 10^{6}\right)$ were injected intraperitoneally in syngeneic A/J mice. After 1 week, the peritoneum was rinsed with sterile saline and the cells further diluted in MEM-Rega3 cell culture medium (Life Technologies, Merelbeke, Belgium). The next in vivo passages $\left(1 \times 10^{4}\right.$ cells $)$ were done in allogeneic C3D2F1 mice, but every 5th passage syngeneic A/J mice were used as the host. For the current experiments, cells were used between in vivo passage $10-$ 20. Mice were subcutaneously inoculated with $1.5 \times 10^{6}$ murine mammary carcinoma TA3-Ha cells at day 0 and randomized into the different experimental groups. Each group consisted of 10 animals for experiments with R116010 and of six animals for experiments with RA. All treatments were performed by oral gavage. Different doses of R116010 (1.25, 0.63, 0.31, 0.16, $0.08 \mathrm{mg} \mathrm{kg}^{-1}$ per dosage) and RA $\left(5,2.5,1.25 \mathrm{mg} \mathrm{kg}^{-1}\right.$ per dosage) were administered on a twice-daily treatment regimen given from day 1 until day 21 . The control groups were given the vehicle $20 \% 4-\mathrm{OH}-\beta$-cyclodextrine in sterile saline. Mice were daily examined for adverse drug effects. At the end of the experiments,

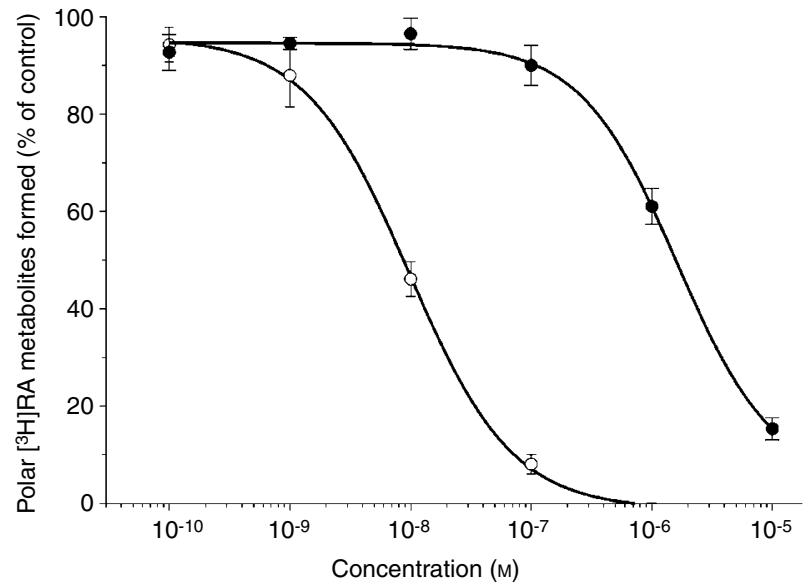

Figure 3 Inhibition of RA metabolism by RII60I0 and liarozole-fumarate. T47D human breast cancer cells were pretreated with I $\mu \mathrm{M}$ RA to induce RA metabolism. Concentration-response curves showing the inhibition by RII60I0 $(\mathrm{O})$ and liarozole-fumarate $(\mathbf{O})$ were determined using the microcolumn assay as described in Materials and Methods. Results are presented as mean \pm s.d. for RII $6010(n=4)$ and liarozole-fumarate $(n=3)$.
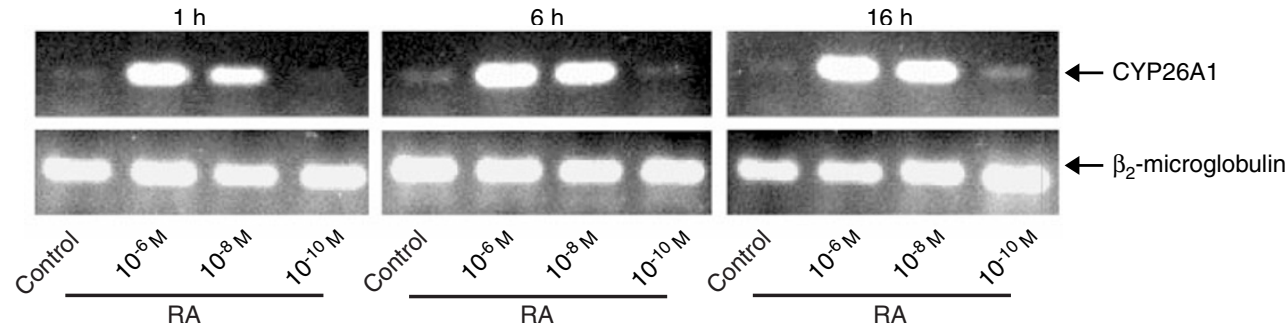

Figure 4 RT - PCR analysis of CYP26AI mRNA expression after treatment with RA. T47D human breast cancer cells were treated with various concentrations of RA for indicated time periods. Thereafter, total RNA was prepared and subjected to RT - PCR. Amplified products were analyzed by agarose gel electrophoresis with ethidium bromide staining. 
subcutaneous tumours were excised $24 \mathrm{~h}$ after the last treatment and weighed to validate the antitumoural effects of the treatment.

Data are represented as box plots showing median group value, 25/ 75th percentile, 10/90th percentile and outliers. Groups were statistically compared to the vehicle-treated groups using the MannWhitney $U$-test. Significance was defined at the level of $P<0.05$.

All animal experiments have been carried out with ethical committee approval. The ethical guidelines that were followed meet the standards required by the UKCCCR Guidelines.

\section{RESULTS}

\section{R116010 is a potent inhibitor of RA metabolism}

Human T47D breast cancer cells, cultured under control conditions, are unable to metabolize RA into more polar metabolites (Figure $2 \mathrm{~A})$. After pretreatment for $16 \mathrm{~h}$ with $1 \mu \mathrm{M}$ RA, T47D cells show extensive RA metabolism (Figure 2B), converting RA into highly polar metabolites (retention time: $3-10 \mathrm{~min}$ ) and several metabolites with intermediate polarity (retention time: 15-25 min), including 4-OH-RA, and 16-OH-RA. RA metabolism is completely inhibited by R116010 at a concentration of $1 \mu \mathrm{M}$ (Figure 2C).

A concentration-response curve (Figure 3), as measured with the quantitative microcolumn method, shows that R116010 inhibits the formation of polar $\left[{ }^{3} \mathrm{H}\right] \mathrm{RA}$ metabolites with a calculated $\mathrm{IC}_{50}$-value of $8.7 \pm 1.4 \mathrm{nM}$. In comparison, R116010 is over 100-fold more potent than liarozole-fumarate, a previously identified inhibitor of RA metabolism, that inhibits RA metabolism with an $\mathrm{IC}_{50}$-value of $1.4 \mu \mathrm{M}$ (Figure 3).

\section{Auto-induction of RA metabolism correlates with induction of CYP26A1}

CYP26A1 is a cytochrome P450-dependent enzyme that specifically metabolizes RA (White et al, 1997). Human T47D breast cancer cells, cultured under control conditions, barely express detectable CYP26A1 mRNA levels (Figure 4). CYP26A1 mRNA expression levels can be induced in a concentration- and time-dependent manner by treatment with RA (Figure 4). The expression levels of CYP26A1 closely correlate with the observed enzyme activity (Figure 2B and data not shown).

\section{R116010 is a selective inhibitor of RA metabolism}

The selectivity of R116010 towards CYP26A1 was tested by determining its inhibition profile against other cytochrome P450-mediated reactions. As shown in Table 1, R116010 inhibits CYP26A1-mediated RA metabolism in microsomes from T47D cells with an $\mathrm{IC}_{50}$-value of $4 \mathrm{nM}$. In contrast, even at high micromolar concentrations $(10 \mu \mathrm{M})$, R116010 barely inhibits other cytochrome P450-mediated reactions, except for limited activity against 17,20 -lyase $\left(\mathrm{IC}_{50}=0.25 \mu \mathrm{M}\right)$.

In comparison, liarozole-fumarate inhibits CYP26A1-mediated $\mathrm{RA}$ metabolism at 100 -fold higher concentrations $\left(\mathrm{IC}_{50}=0.5 \mu \mathrm{M}\right)$
(Table 1). At this concentration liarozole-fumarate also clearly inhibits other cytochrome P450-mediated reactions (Table 1).

\section{R116010 enhances the antiproliferative activity of RA}

RA inhibits T47D cell proliferation in a concentration-dependent manner (Figure 5A,B) with a calculated $\mathrm{IC}_{50}$-value of
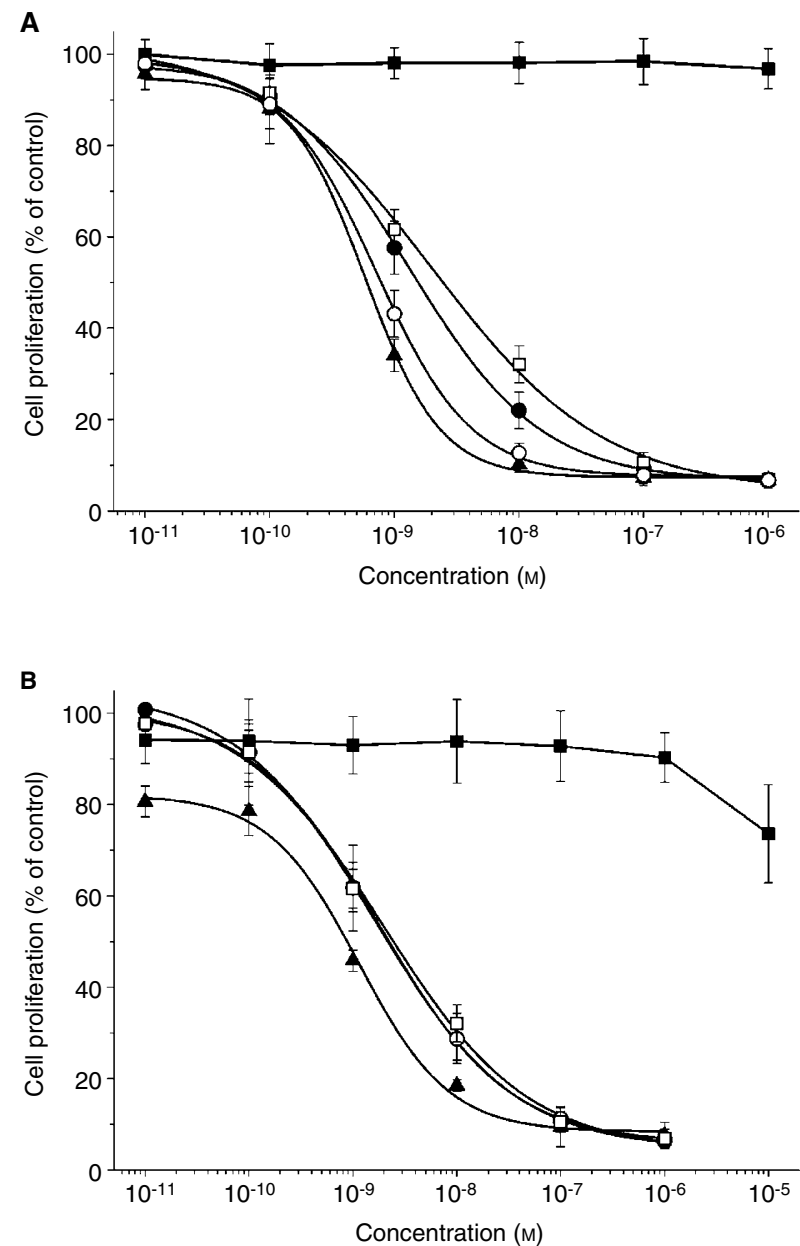

Figure 5 Concentration-response curves showing the antiproliferative effects of (A) RA $(\square)$, RII60I0 ( $)$ and RA in combination with RII60I0 (O: 0.0I $\mu \mathrm{M}$; O: 0.I $\mu \mathrm{M} ; \mathbf{\Delta}:$ I $\mu \mathrm{M})$ or $(\mathbf{B}) \mathrm{RA}(\square)$, liarozole-fumarate $(\mathbf{)})$ and $R A$ in combination with liarozole-fumarate $(0.1 \mu \mathrm{M} ; 0$ I $\mu \mathrm{M} ; \mathbf{A}: 10 \mu \mathrm{M})$ in T47D cells. Cell proliferation was measured after 7 days using a MTT-based assay as described in detail in Materials and Methods. Results are presented as mean \pm s.d. for RII60I0 (n=4) and liarozolefumarate $(n=3)$.

Table I In vitro cytochrome P450 isozyme profile for RII60I0 and liarozole-fumarate

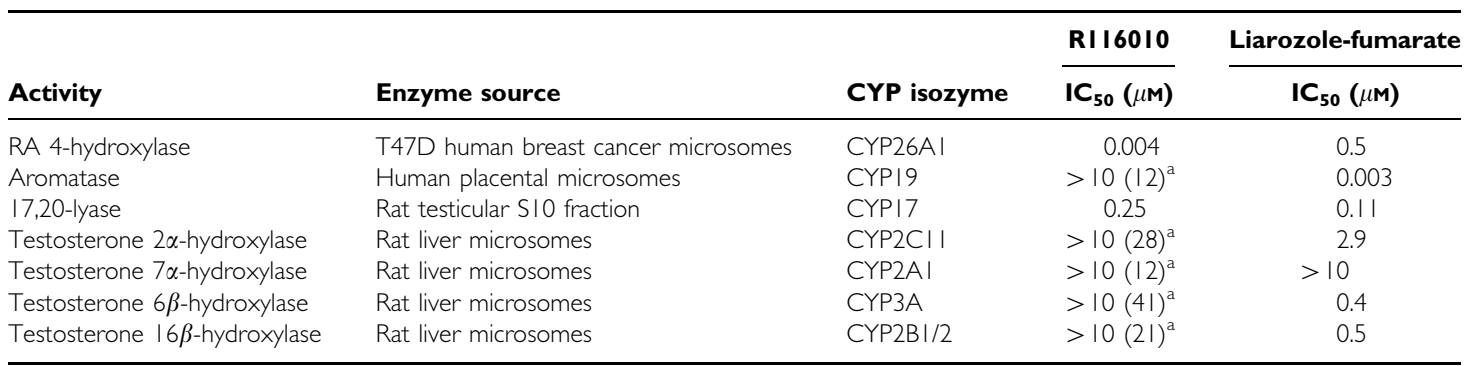

a $V$ alues between parentheses represent percentage of inhibition of $10 \mu \mathrm{M}$ R I I60 I0 
$2.0 \pm 0.5 \mathrm{nM}$ (Table 2). R116010 by itself has no effect on T47D cell proliferation (Figure 5A). However, in combination with RA, R116010 enhances the antiproliferative activity of RA in a concentration-dependent manner (Figure 5A). At a concentration of $0.01 \mu \mathrm{M} \mathrm{R} 116010$ enhances the antiproliferative activity of RA by 1.25 -fold ( $\mathrm{IC}_{50}$-value $=1.6 \pm 0.6 \mathrm{nM}$ ), at $0.1 \mu \mathrm{M} \mathrm{R} 116010$ by 2.6 -fold $\left(\mathrm{IC}_{50}\right.$-value $\left.=0.77 \pm 0.18 \mathrm{nM}\right)$ and at $1 \mu \mathrm{M} \mathrm{R} 116010$ by three-fold $\left(\mathrm{IC}_{50}\right.$-value $\left.=0.62 \pm 0.19 \mathrm{nM}\right)$.

In contrast, liarozole-fumarate, tested up to a concentration of $10 \mu \mathrm{M}$, is unable to enhance the antiproliferative activity of RA (Figure 5B). At this concentration $(10 \mu \mathrm{M})$, liarozole-fumarate by itself decreases T47D cell proliferation by approximately $25 \%$ (Figure 5B). This decrease in T47D cell proliferation at $10 \mu \mathrm{M}$ explains the apparent enhancement of RA activity, which is actually the effect of liarozole-fumarate alone (Figure 5B).

\section{R116010 inhibits the growth of murine TA3-Ha mammary tumours in vivo}

Mice subcutaneously inoculated with oestrogen-independent TA3$\mathrm{Ha}$ cells were treated twice-daily with RA (Figure 6A) or R116010 (Figure 6B) from day 1 until day 21. As shown in Figure 6A, RA inhibits TA3-Ha tumour growth in a dose-dependent manner. The lowest active dose is $2.5 \mathrm{mg} \mathrm{kg}^{-1}$. At a dose of $5 \mathrm{mg} \mathrm{kg}^{-1}$, mice lost $5 \%$ of body weight (data not shown) and toxicity was observed, which consisted mainly of hair loss, and impaired movement due to bone fractures.
R116010 potently inhibits TA3-Ha tumour growth at doses as low as $0.16 \mathrm{mg} \mathrm{kg}^{-1}$ (Figure 6B). R116010 is approximately 60fold more potent than liarozole-fumarate which in this model inhibits tumour growth only at $10 \mathrm{mg} \mathrm{kg}^{-1}$ (data not shown). Toxicity, related to hypervitaminosis $\mathrm{A}$, was observed at a dose of $5 \mathrm{mg} \mathrm{kg}{ }^{-1}$ for R116010 and at $20 \mathrm{mg} \mathrm{kg}^{-1}$ for liarozole fumarate. At these doses hair loss and bone fractures were observed, and body weight decreased by $\sim 15 \%$ (data not shown).

\section{DISCUSSION}

The prompt emergence of resistance to RA treatment is a major hurdle in the clinical development of RA (Muindi et al, 1992; Miller, 1998). Drugs which are able to inhibit RA metabolism may therefore prove valuable in the treatment of cancer. In this study, we have identified R116010 as a highly potent and selective inhibitor of RA metabolism.

Human breast T47D carcinoma cells are known to have an inducible RA metabolism (Han and Choi, 1996; Van der Leede et al, 1997). The capacity to metabolize RA closely correlates with the expression level of CYP26A1, a cytochrome P450-dependent enzyme that specifically metabolizes RA (White et al, 1997). In untreated T47D cells, which are unable to metabolize RA, CYP26A1 expression is barely detectable. Treatment with RA rapidly induces the capacity to metabolize RA (Han and Choi, 1996), which is correlated with a strong induction of CYP26A1, in agreement with a previous report (Sonneveld et al, 1998). In intact T47D cells, R116010 potently inhibits RA metabolism with
A

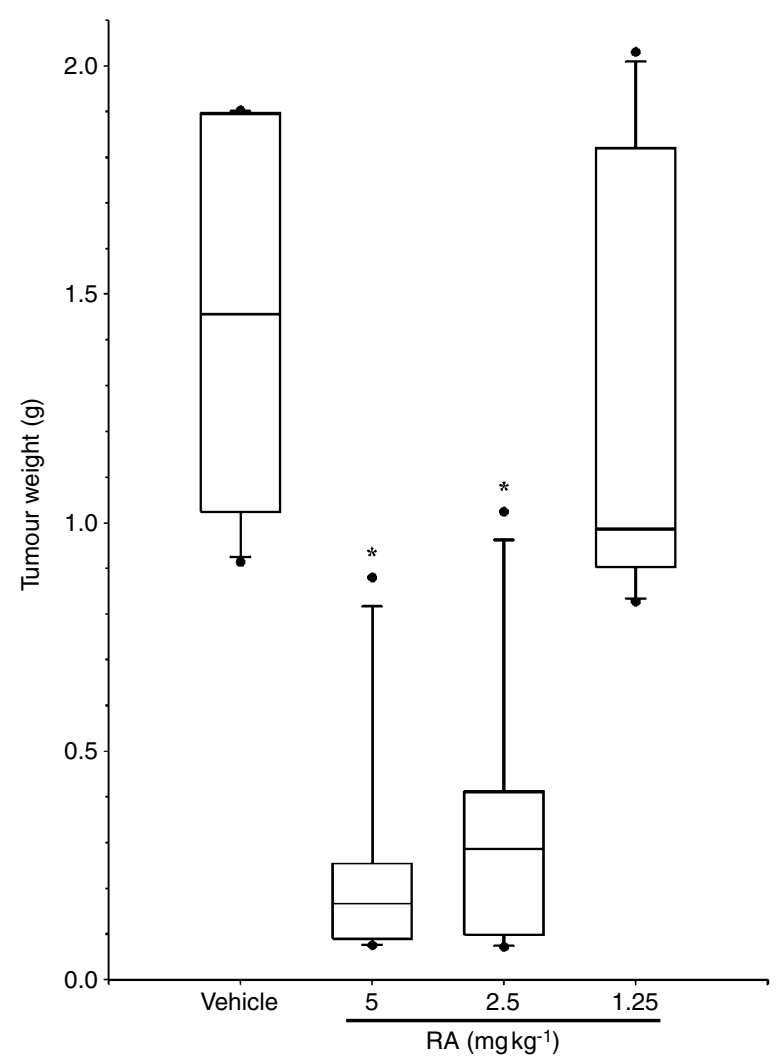

B

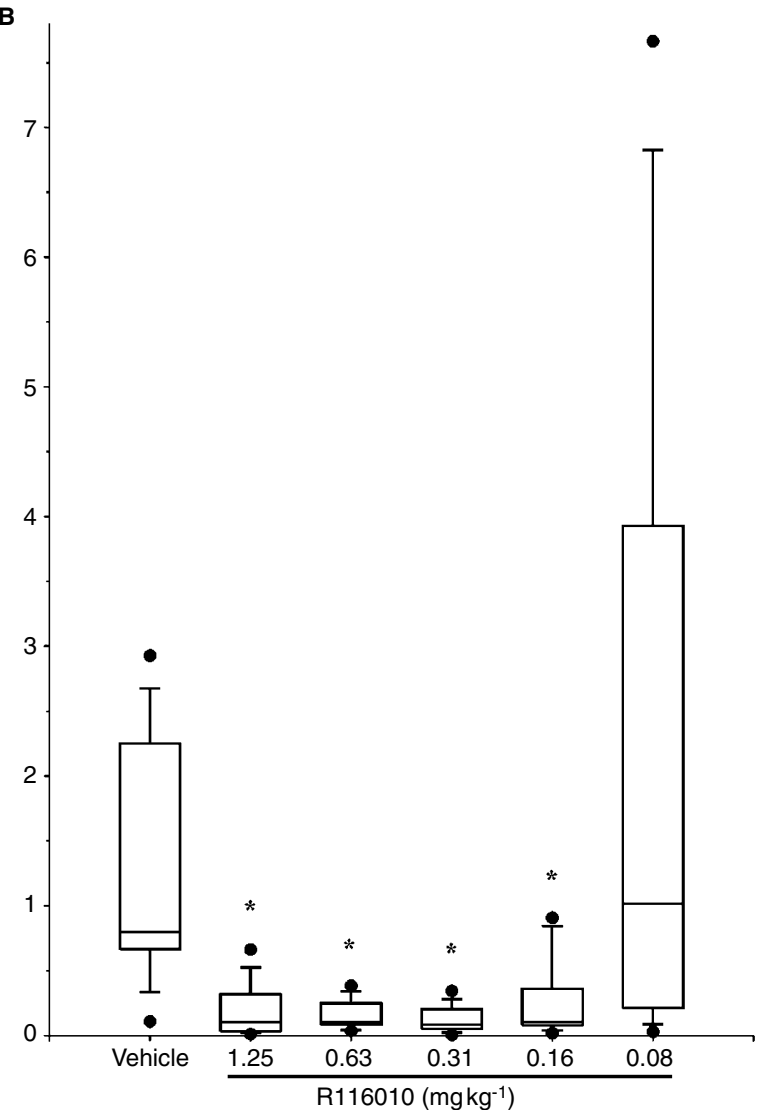

Figure 6 In vivo antitumour activity of RA $(\mathbf{A})$ and $\mathrm{RII60I0}(\mathbf{B})$ in the murine TA3-Ha tumour model. TA3-HA mammary carcinoma cells $\left(1.5 \times 10^{6}\right)$ were subcutaneously inoculated in mice. RA (A) or RII 6010 (B) was given by oral treatment twice daily from day I until day 21 . Tumours were excised $24 \mathrm{~h}$ after the last treatment and weighed. Data are represented as box plots showing median group value, 25/75th percentile, I0/90th percentile and outliers. Groups were statistically compared to the vehicle-treated groups using the Mann-Whitney U-test. Statistical significance was defined at the level of $* P<0.05$. 
an $\mathrm{IC}_{50}$-value of $8.7 \mathrm{nM}$. As such, $\mathrm{R} 116010$ is more than 100 -fold more potent than liarozole-fumarate, a previously identified inhibitor of RA metabolism (Wouters et al, 1992).

As well as being a more potent inhibitor of RA metabolism, R116010 is also more selective as compared to liarozole-fumarate. Although our in vitro data suggest that R116010 might affect androgen levels by inhibiting 17,20-lyase, no change on blood hormone levels could be detected in rats treated with a high dose (10 $\mathrm{mg} \mathrm{kg}^{-1}$ ) of R116010 (data not shown). Liarozole-fumarate is much less specific. It is a potent aromatase inhibitor (Bruynseels et $a l, 1990$ ), and in addition it also inhibits other cytochrome P450mediated reactions, thereby affecting hormone levels both in animals and in humans (Bruynseels et al, 1990). Taken together, these data suggest that R116010 is less likely to produce adverse side effects.

In T47D cell proliferation experiments, R116010 enhances the antiproliferative activity of RA in a concentration-dependent manner. Concentrations effective in enhancing the biological activity of RA, are identical to the concentrations that are needed to inhibit RA metabolism in intact cells. Therefore, these data support the hypothesis that R116010 enhances the biological activity of RA through inhibition of RA metabolism. Liarozole-fumarate is unable to enhance the antiproliferative activity of RA in T47D cells. This is in contrast to our previous data, which clearly showed that liarozole-fumarate is able to enhance both the antiproliferative and differentiation-inducing activity of RA in MCF-7 human breast cancer cells (Wouters et al, 1992; Van heusden et al, 1996). This apparent contradiction might be explained by the fact that T47D cells are known to metabolize RA at a much higher rate than MCF-7 cells (Van der Leede et al, 1997; unpublished results) and that liarozole-fumarate is therefore not potent enough to effectively inhibit RA metabolism in T47D cells.

In vivo, R116010 has been shown to inhibit the growth of orthotopically implanted androgen-independent rat prostatic Dunning R3327/PIF-1 carcinoma cells (Van Ginckel et al, 1999), and of subcutaneous mouse Lewis lung (3LL) tumours (Smets et al, manuscript in preparation). In this study, the in vivo activity of

\section{REFERENCES}

Achkar CC, Bentel JM, Boylan JF, Scher HI, Gudas L, Miller Jr WH (1994) Differences in the pharmacokinetic properties of orally administered alltrans-retinoic acid and 9-cis-retinoic acid in the plasma of nude mice. Drug Metab Dispos 22: $451-458$

Bruynseels J, De Coster R, Van Rooy P, Wouters W, Coene M-C, Snoeck E Raeymaekers A, Freyne E, Sanz G, Vanden Bussche G, Vanden Bossche H, Willemsens G, Janssen PAJ (1990) R75251, a new inhibitor of steroid biosynthesis. Prostate 16: $345-357$

Dijkman GA, Van Moorselaar RJA, Van Ginckel R, Van Stratum P, Wouters L, Debruyne FMJ, Schalken JA, De Coster R (1994) Antitumoral effects of liarozole in androgen-dependent and -independnet R3327-Dunning prostate adenocarcinomas. J Urol 151: $217-222$

Garrabrant TA, End DW (1995) A rapid assay for measuring the metabolism of $\left[{ }^{3} \mathrm{H}\right]$-retinoic acid in cell cultures. J Pharmacol Toxicol Meth 34: $219-$ 223

Han IS, Choi J-H (1996) Highly specific cytochrome P450-like enzymes for all-trans-retinoic acid in T47D human breast cancer cells. J Clin Endocrino Metab 81: $2069-2075$

Hong WK, Itri LM (1994) Retinoids and human cancer. In The Retinoids. Biology, Chemistry and Medicine, 2nd edn, Sporn MB, Roberts AB, Goodman DS (eds) pp 597-630. New York: Raven Press Ltd.

Krekels MDWG, Verhoeven A, van Dun J, Cools W, Van Hove C, Dillen L, Coene M-C, Wouters W (1997) Induction of the oxidative catabolism of retinoic acid in MCF-7 cells. Br J Cancer 75: 1098-1104

Lee JS, Newman RA, Lippman SM, Huber MH, Minor T, Raber MN, Krakoff IH, Hong WK (1993) Phase I evaluation of all-trans-retinoic acid in adults with solid tumors. J Clin Oncol 11: 959-966
R116010 has been evaluated in the murine oestrogen-independent TA3-Ha mammary carcinoma model. An oestrogen-independent model was chosen to exclude any hormonal mechanism of action. In addition, TA3-Ha cells are known to actively metabolize RA (Garrabrant and End, 1995) and TA3-Ha tumours are sensitive to RA treatment (Wouters et al, 1990). Indeed, treatment with RA inhibits TA3-Ha tumour growth in a dose-dependent manner. However, keeping in mind that the lowest active dose is $2.5 \mathrm{mg} \mathrm{kg}^{-1}$ and that the maximum tolerable dose is $5 \mathrm{mg} \mathrm{kg}^{-1}$, RA does not show a real therapeutic window. Similarly, liarozole-fumarate has no therapeutic window since a dose of $10 \mathrm{mg} \mathrm{kg}^{-1}$ has to be used to induce antitumour activity, and the maximum tolerated dose is $20 \mathrm{mg} \mathrm{kg}^{-1}$ (data not shown). In sharp contrast, R116010 inhibits TA3-Ha tumour growth at doses as low as $0.16 \mathrm{mg} \mathrm{kg}^{-1}$. With a maximum tolerated dose of $5 \mathrm{mg} \mathrm{kg}^{-1}$, R116010 exhibits a 30-fold therapeutic window. We speculate that this larger therapeutic window is due to the intratumoural action of R116010, thereby increasing intracellular levels of RA, while RA mainly remains in the circulation, and much higher doses are needed to produce a biological response. Given that R116010 has a broader therapeutic window, one can argue that R116010 may be a more effective anticancer drug. The observation of retinoid-like side effects at higher doses reinforces the hypothesis that R116010 exerts its antitumour activity via RA.

In conclusion, R116010 has been identified as a potent and selective inhibitor of RA metabolism. Inhibition of RA metabolism leads to an enhancement of the antiproliferative activity of RA both in vitro and in vivo. Inhibitors of RA metabolism may therefore represent a novel class of anticancer agents.

\section{ACKNOWLEDGEMENTS}

The authors thank M Heylen, and L Leijssen for their skillful assistance in preparing this manuscript. We are very grateful to Dr M Klaus (Hoffmann-La-Roche, Basle, Switzerland) for the generous gift of the retinoids.
Miller VA, Rigas JR, Muindi JRF, Tong WP, Venkatraman E, Kris MG Warrell Jr RP (1994) Modulation of all-trans-retinoic acid pharmacokinetics by liarozole. Cancer Chemother Pharmacol 34: 522-526

Miller WH (1998) The emerging role of retinoids and retinoic acid metabolism blocking agents in the treatment of cancer. Cancer 83: $1471-1482$

Moon RC, Mehta RG, Rao KVN (1994) Retinoids and cancer in experimental animals. In The Retinoids. Biology, Chemistry and Medicine, 2nd edn, Sporn MB, Roberts AB, Goodman DS (eds) pp 573-595. New York: Raven Press, Ltd.

Muindi J, Frankel SR, Miller Jr WH, Jakubowski A, Scheinberg DA, Young CW, Dmitrovski E, Warrell Jr RP (1992) Continuous treatment with alltrans-retinoic acid causes a progressive reduction in plasma drug concentrations: implications for relapse and retinoid 'resistance' in patients with acute promyelocytic leukemia. Blood 79: 299-303

Muindi JF, Scher HI, Rigas JR, Warrell Jr RP, Young CW (1994) Elevated plasma lipid peroxide content correlates with rapid plasma clearance of all-trans-retinoic acid in patients with advanced cancer. Cancer Res 54: $2125-2128$

Smets G, Van Ginckel R, Daneels G, Moeremans M, Van Wauwe J, Coene MC, Ramaekers FCS, Schalken JA, Borgers M, De Coster R (1995) Liarozole, an antitumor drug, modulates cytokeratin expression in the Dunning AT6sq prostatic carcinoma through in situ accumulation of all-trans-retinoic acid. Prostate 27: $129-140$ 
Sonneveld E, van den Brink CE, van der Leede B-jM, Schulkes R-KAM, Petkovich M, van der Burg B, van der Saag PT (1998) Human retinoic acid (RA) 4-hydroxylase (CYP26) is highly specific for all-trans-RA and can be induced through RA receptors in human breast and colon carcinoma cells. Cell Growth Diff 9: 629-637

Van der Leede B-j, van den Brink CE, Pijnappel WWM, Sonneveld E, van der Saag PT, van der Burg B (1997) Autoinduction of retinoic acid metabolism to polar derivatives with decreased biological activity in retinoic acid-sensitive, but not in retinoic acid-resistant human breast cancer cells. J Biol Chem 272: $17921-17928$

Van Ginckel R, De Coster R, Wouters W, Vanherck W, van der Veer R, Goeminne N, Jagers E, Van Cauteren H, Wouters L, Distelmans W, Janssen PAJ (1990) Antitumoral effects of R75251 on the growth of transplantable $\mathrm{R} 3327$ prostatic adenocarcinoma in rats. Prostate 16: $313-323$

Van Ginckel R, Floren W, Moelans P, Janssens B, Molenberghs K, van Dun J, Venet M, Mabire D, Wouters W (1999) Antitumoral effects of R116010, a retinoic acid metabolism inhibitor of the second generation, on experimental tumors in vivo. Proc Amer Assoc Cancer Res 40: 2615

Van heusden J, Borgers M, Ramaekers FCS, Xhonneux B, Wouters W, De Coster R, Smets G (1996) Liarozole potentiates the all-trans-retinoic acid-induced structural remodelling in human breast carcinoma MCF-7 cells in vitro. Eur J Cell Biol 71: 89-98

Van heusden J, Wouters W, Ramaekers F, Krekels MDWG, Dillen L, Borgers M, Smets G (1998) The antiproliferative activity of all-trans-retinoic acid catabolites and isomers is differentially modulated by liarozole-fumarate in MCF-7 human breast cancer cells. Br J Cancer 77: 1229-1235
Van Wauwe J, Coene M-C, Cools W, Goossens J, Lauwers W, Le Jeune L, Van Hove C, Van Nyen G (1994) Liarozole fumarate inhibits the metabolism of 4-keto-all-trans-retinoic acid. Biochem Pharmac 47: 737-741

Vanden Bossche H, Willemsens G, Roels I, Bellens D, Moereels H, Le Jeune L, Lauwers W, Janssen PAJ (1990) R76713 and its enantiomers: selective, nonsteroidal inhibitors of the cytochrome P450-dependent estrogen synthesis. Biochem Pharmac 40: 1707-1719

Vanden Bossche H (1992) Inhibitors of P450-dependent steroid biosynthesis: from research to medical treatment. J Steroid Biochem Molec Biol 43: $1003-1021$

Westarp ME, Westarp MP, Bruynseels J, Bollag W, Kornhuber H-H (1993) Oral liarozole as a catabolic inhibitor potently increases retinoic acid in vivo: first experience from an ongoing therapeutic trial in highly malignant primary brain tumors. Onkologie 16: $22-25$

White JA, Beckett-Jones B, Guo Y-D, Dilworth FJ, Bonasoro J, Jones G, Petkovich M (1997) cDNA cloning of human retinoic acid-metabolizing enzyme (hP450RAI) identifies a novel family of cytochromes P450 (CYP26). J Biol Chem 272: 18538 - 18541

Wouters W, De Coster R, Van Ginckel R, Vanherck W, Beerens D, van Dun J, Van Cauteren H, Amery W (1990) Antitumoral activity of R75251 in experimental models. Proc Amer Assoc Cancer Res 31: 414

Wouters W, van Dun J, Dillen A, Coene M-C, Cools W, De Coster R (1992) Effects of liarozole, a new antitumoral compound, on retinoic acidinduced inhibition of cell growth and on retinoic acid metabolism in MCF-7 human breast cancer cells. Cancer Res 52: 2841-2846 